\title{
Building Customer Engagement Through User- Generated Content: A Case Study on @Bt21Stuff.Id
}

\author{
Aimee Anindya Putri ${ }^{1} \&$ Elke Alexandrina ${ }^{2}$ \\ LSPR Communication and Business Institute, Jakarta, Indonesia
}

\begin{abstract}
As the popularity of K-Pop culture increases rapidly in Indonesia, many people started to see this as an opportunity to start a business. The business which started to get popular amongst K-Pop fans community nowadays is an online shopping entrusted goods service business which specialized in providing a service to help K-Pop fans in purchasing their favorite idol merchandises directly from South Korea. The competition for this online shopping entrusted goods service business keeps growing and increases every day, due to the popularity of K-Pop and the customers plays a crucial role in this business. Therefore, maintaining a customer engagement for this business is very necessary. The objective of this research is to reveal the contribution of user generated content created by the customers as a way to build customer engagement of @bt21stuff.id and also to reveal the motivations behind the creation of user generated content by the customers. This research is using a qualitative methodology and guided by using the concept of customer engagement cycle by Sashi (2012). The findings of this research shows that the user generated content plays a role in each stage of the customer engagement cycle and that the customers are mostly motivated by the empowerment motives in creating the user generated content.
\end{abstract}

Keywords: Online Shopping Entrusted Goods Service; K-Pop; Customer Engagement; User Generated Content; Instagram

\section{INTRODUCTION}

The spread of COVID-19 pandemic which started last year in the beginning of 2020 caused the increasing number of active internet users in Indonesia. The data retrieved from Data Reportal shows that there were approximately more than 200 million internet users and 170 million social media users in the beginning of 2021. This number is equal to $61,8 \%$ from the total population of Indonesian in January 2021 (Kemp, 2021).

The rapid development of the internet and technology in this digital era along with the dramatic increase on social media users in Indonesia due to the spread of COVID-19 pandemic as stated in the previous paragraph can be a huge opportunity for business owner to start promoting their business through online platforms considering the fact that most people in this digital era started to spend more time online. Moreover, (Putri, 2019 p. 4) stated that in this digital era, many people prefer to do online shopping due to its effectiveness. Not only that online shopping is more effective and convenient for the customers, it is also a lot more cost-efficient for the owner of the business, since online business requires less money for its operations and also promotions (Putri, 2019, p. 4).

The famous term for one popular form of online shopping is known as online shopping entrusted goods service or as known as jasa titip in Indonesian. Online shopping entrusted 
goods service started to become popular in Indonesia around 5 years ago back in 2016 (Putri, 2019, p. 6). The popularity of this shopping entrusted goods service is due to the fact that there are many products that are available in some countries, but are not available here in Indonesia. The existence of this service is actually to help and assist the customers in buying the product that they want but can't get here in Indonesia by charging them an extra amount of money.

The popularity of online shopping entrusted goods service increased when the Korean Wave started to become huge in Indonesia. According to brandinginasia.com, Indonesia is included as one of the top three countries with the highest tweets of K-Pop on Twitter as in 2020 right below Thailand which ranked first and South Korea which ranked second in the world (Pantalon, 2020). Twitter users in Indonesia mostly tweeted about BTS, EXO, TXT, NCT 127 and Stray Kids (Kim, 2021). This shows that a lot of Indonesian put their interest towards Korean Pop or K-Pop. Due to the Korean Wave trend, the demand from K-Pop fans on K-Pop related goods or merchandises such as K-Pop albums increased rapidly. Thus, to fulfill the demand from these K-Pop fans there are a lot of online shops who offer this online shopping entrusted goods service specialized for K-Pop goods and merchandise. One of it is @bt21stuff.id. The existence of online shopping entrusted goods service for K-Pop goods really helps and eases the K-Pop fans to purchase a product of their favorite groups or artists due to the fact that buying goods or merchandises directly from South Korea would be complicated and would cost a lot. Even sometimes up to the point where the cost for shipping and tax exceeded the price of the goods.

Started the business in the middle of 2019, @bt21stuff.id has gained more than 41.000 followers on their official Instagram account as of today in 2021. Besides Instagram, the other platforms that they use to operate their business are WhatsApp, Shopee Indonesia, and Shopee International which can be accessed by four countries including Singapore, Thailand, Malaysia, and Taiwan. @Bt21stuff.id utilizes their official instagram account as an interactive marketing communication tool with their customers to share the detailed information for a pre-order, upcoming, or products that are already ready to buy mostly through their instagram feed and story or as known as snapgram. Not only they share informations regarding the products that they sell, they also often re-share the user generated content created by their customers in the form of photo or video testimonials on their Instagram story.

As a business which moves in a service industry which offers online shopping entrusted goods service, @bt21stuff.id really relies on their customers to expand their business. Therefore, since instagram is an accessible online platform where they can interact most with their current customers and potential customers, this research will be more focused on @bt21stuff.id Instagram account instead of their other platforms.

In purpose for their business to develop and be on the top list of the K-Pop related goods shopping entrusted goods service market, they really need to gain their customers' trust and engage with their customers through their social media in order to attract more potential customers to come and use their service instead of using other businesses which offer the exact same service with them. Therefore, in order to have a special relationship with the customers, a business needs to build a sustainable engagement with their customers (Qysthina et al., 2018, p. 3574).

Online businesses that have good relationships and successfully build a sustainable 
engagement with their followers on Instagram can also drive potential customers to be more convinced that their business can be trusted (Rohadian \& Amir, 2019 p. 180). This shows that customer engagement is very important for a business, especially online business such as online shopping entrusted goods service which requires high trust from the customers.

Moreover, Larivière et al., (2017, p. 4) stated that the role of customers in this digital era has changed. The customers are no longer the passive parties in the business. According to Larivière et al., (on Shawky et al., 2020 p. 2), now the customers also involved in development and delivery of new services or products, building communities, engaging with the other customers and prospects, interacting with non-customers, and differentiating between multiple offers in the marketplace.

User generated content which related to a certain brand that is created by the customers is one form of the customers' contribution through virtual. User generated content is a content in the form of photos, videos, or even blogs which consist of information uploaded by the user, or the customers, to their own social media or any other web-based application to review the product or service that they've purchased (Bruns, 2016, p. 1-3).

Gomez et al., (on Shawky et al., 2020 p. 2) argues that customers in this digital era also contribute to the company's message by becoming the generator for information, reviewers and influencers, who increasingly influenced other customers' preferences and purchase decisions. They added that the content generated by the customers contribute in building the engagement of a company.

Shawky et al., (2020, p. 7) also found that customers' advocacy represents the highest level of engagement and actively empowers other customers to also engage to the company. This shows that the contribution of customers towards the company in the form of user generated content plays a role in building the customer engagement.

According to Sherman \& Smith (2013 p. 11-12) customers in this digital era have higher expectation from a company compared to the customer in the previous era. They stated that in this era customers expect the company to listen to them when they give reviews about the brand. Customers in this era like to willingly post feedback or reviews about the products or services they've purchased on their personal social media platform. Whether the review is good or bad, a company needs to pay attention to the customers' reviews and give responses (Sherman \& Smith, 2013 p. 11-12).

@Bt21stuff.id is one of the K-Pop related online shopping entrusted goods service in Indonesia that regularly responds to user generated content created by their customers by reposting it through their Instagram story. The rampage competition of this K-Pop related online shopping entrusted goods service is arising, therefore @bt21stuff.id needs to maintain and expand their relationship with the customers by building a sustainable engagement in purpose to stay on top list of the K-Pop related online shopping entrusted goods service market.

\section{Customer Engagement Process}

Customer engagement is a behavior which drive the customer into willingly give a voluntary contribution to the brand or a company, whereas the contribution is beyond a transaction process (Jaakkola \& Alexander, 2014, p. 248). Meanwhile (Strauss \& Frost, 2012, p. 34-35) 
stated that engagement happens when customers is connected emotionally and intellectually (cognitively) to a certain brand. They also stated that engaged customers will more likely to become attentive and favorable towards the brand.

Sashi (2012, p. 264) stated that customer engagement can broaden the customer's role in a business by involving the customer in the process of giving feedback or review. By doing so, customers will feel like they are important to the company, and that the company cares about them which has a great potential in building customer engagement. Moreover, he also stated that interactivity on social media greatly facilitates the process of forming intimate relationships with trust and commitment between the seller and the buyer (Sashi, 2012, p. 260). Therefore, a company needs to fully utilize their social media platforms to build an engagement with their customers.

In regard to this, (Sashi, 2012, p. 260) construct a customer engagement building process into a customer engagement cycle which consist of (1) Connection: in purpose for the establishment of relational exchange with emotional bonds, it takes seller and the customers to connect with one another. In this digital era, connection between seller and customers can be established through digital platforms such as social media. Through social media, seller can build relationship with the customers and also non-customers in large numbers in a very convenient way; (2) Interaction: once the connection between the seller and customers has been established, the process will proceed into interaction. Not only with the seller, customers can also interact with other customers through digital platforms, such as social media. Seller can utilize the interaction amongst customers to discover the customers' needs and wants towards their business; (3) Satisfaction: only when the customers are satisfied with the interaction process will they continue to interact with the brand and proceed towards the customer engagement; (4) Retention: this stage is achieved from the overall satisfaction of the customers from time to time or a high positive emotion. There are two factors that might caused customer retention which are enduring relationship without emotional bonds and emotional bonds without long-term relationship; (5) Commitment: there are 2 types of commitment in a customer relationship. There are affective commitment and also calculative commitment. While calculative commitment is more rational, an affective commitment is more emotional and comes from the feeling of trust between the customers and the seller; (6) Advocacy: a happy customer will enjoy the happiness they feel with their own self or share it to other people through their social media platforms. Loyal customers that are lacking of emotional bonds will most likely won't share their personal experience upon using a certain brand. However, a delighted and loyal customers will most likely share their positive experience upon using a certain brand through online platforms, or traditional word of mouth; (7) The process can proceed to an engagement when satisfied and happy customers share their positive experience with their peers about the product, service, brand or company that they interact with. Research that has been done by (Shawky et al., 2020 p.7) also also found that customers' advocacy represents the highest level of engagement and actively encourage other customers to also engage to the company.

Therefore, based on the explanation above, this research is using the customer engagement cycle by Sashi (2012) as the theoretical foundation to reavel how the customer advocacy in the form of user generated content contribute to each stage of the customer engagement building process. 


\section{Uses and Gratification Theory}

This research is also using the uses and gratification theory that was first being introduced by Blumer \& Katz in the 1974 in their book with the title of The Uses on Mass Communication: Current Perspectives on Gratification Research (Nurudin, 2019). The old version of this theory is oftenly used for research that are related to customer behavior in conventional media. However, with the existence of the internet as a new interactive communication platform, this theory is then being developed and also being applied significantly to research about social media (Ngai et al., 2015 p. 35).

The newest version of this theory stated that the user of social media plays an active role in choosing and using the media. Therefore, the application of uses and gratification theory is now used by various researchers, especially research which studies regarding social media to explore the uses and motives behind social media usage by the audience (Dunne et al., 2010, p. 47).

Adapting from the concept proposed by McQuail and Muntinga, Smit, \& Moorman regarding the motivations of why the audience uses social media based on the uses and gratification theory to study more regarding the motivations of consumers' online brand related activities (COBRAs), (Buzeta, et al., 2020 p. 80) propose 6 uses and gratification theory as driving motivations of the social media usage by the audience. The driving motivations proposed by (Buzeta, et al., 2020, p. 81) are including (1) Entertainment, to generate an emotional relief; (2) Integration and social interaction, which occurs when the audience uses the media as a substitute for a friend; (3) Personal identity, as a way to strengthen individual values from receiving recognition from peers; (4) Information, the motivation to gain information and understanding regarding certain topics or events; (5) Remuneration, the intention of gaining benefit or rewards; (6) Empowerment, to influence the other audience perception towards a certain things (Buzeta et al., 2020 p. 81)

The newest and updated version of the uses and gratification theory is applied in certain cases as a means to understand how various social media platforms successfully attract customers from the other customers through user generated content and also to understand regarding the motivations of why the customer created the user generated content of a certain brand.

Therefore, the updated version of uses and gratification theory by (Buzeta et al., 2020) will also be used in this research as a supporting theoretical foundation to reveal the driving motivations behind the creation of user generated content that is related to a certain brand by the customers.

\section{User-Generated Content}

User generated content is defined as a creative content created by customers that is provided by the media transmission that is publicly accessible such as the internet which reflects multiple effects of creative efforts and are created for free outside of professional practice (Christodoulides et al., 2012, p. 54). Christodoulides et al., (2012 p. 53) also mentioned that user generated content includes brand-related content in the form of blogs, videos, photos, etc., which are uploaded to various social media platforms such as Facebook, YouTube, or Twitter by the customers. 
Meanwhile according to (Bruns, 2016, p. 1-3) user generated content is a content in the form of photos, videos, or even blogs which consist of information uploaded by the user, or the customers, to their own social media or any other web-based application to review the product or service that they've purchase. Unlike the previous years where the internet wasn't as developed as it is today, customers now play a big role in the business. The content they make and share can sometimes significantly affect the company. User generated content is believed to also increase the engagement between the company and the customers (Shawky et al., 2020).

\section{METHOD}

This research is implemented by using a qualitative methodology that will result in a descriptive data in the form of written words and not numbers (Moleong, 2011). The paradigm that is being used in this research is constructivist paradigm, in which according to (Patton, 2002, p. 96-97) research which utilizes the constructivist paradigm strategy suggests that each way of how individuals see the world is valid, and people need respect for their views. Meaning that the constructivists paradigm believes that there's no right or wrong since each person have different perspective towards a certain phenomenon.

For primary data, this research is using an in-depth interview technique with semi-structured interview model. In the semi-structured interview model, the interviewer is equipped with a set of questions that later will be able to be developed in accordance with the development of the interview process (Rachmawati, 2007). In this interview model, the interviewer will be able to freely follow up on related topics that might appear during the interview process (Rachmawati, 2007).

According to Hendarsono in Suyanto (2005), there are 3 types of research informants which are including (1) Key Informant, the people who knows and have variety of basic informations needed in the research, which is the owner of @bt21stuff.id; (2) Main Informants, the people who are directly involved in the social research interaction, which are 3 customers of @bt21stuff.id who have made user generated content upon purchasing goods from the business; (3) Additional Informant, the people who can provide information even though they are not directly involved in the social interaction that is being researched, which is 1 digital marketing expert with more than 5 years of experience in the digital marketing field.

In theoretical base, this research is using Miles \& Huberman models on Sugiyono (2015) for data analysis method which are data reduction, data display, and conclusion drawing/verification. To testify the validity of the data, source triangulation technique is being used in this research. Sugiyono (2015) stated that source triangulation technique is testing the data credibility by checking all of the data that has been obtained through several sources.

\section{RESULT AND ANALYSIS}

The findings of this research shows that the user generated content plays a role in each stage of the customer engagement building process. The existence of user generated content created and shared by the customers of @bt21stuff.id contribute in each stage of the customer 
engagement cycle, starting from the connection stage into advocacy stage that will lead into the establishment of the final stage of the cycle, which is an engagement.

\section{Connection}

In establishing the connection with the potential customers, the owner of @bt21stuff.id explained that the role of user generated content created by the current customers in the form of photos or videos uploaded and shared to their personal Instagram story is very effective to attract new customers.

"One of my customers posted an unboxing video to her Instagram story, and because of that video I got several orders for the same item. The new customers gave me a screenshot of the video that was being shared and asked whether the item is still available or not. And that is where I got new customers." (A. Azhari, Personal Communication, 23 July 2021).

According to (Sashi, 2012, p. 260) connection is the prerequisite stage before the seller and the customers establish a relational exchange and emotional bonds with each other. Therefore, it is very important for a brand to connect with the customers so that they can create an engagement with the customers. In purpose of the connection to develop, an awareness is needed.

Therefore, in the connection stage it is found that the customers act as the provider for information and reviewers (Gomez et al., on Shawky et al., 2020, p. 2) by creating and sharing the user generated content and it is found that their action is impacting the awareness of the brand and also the further behavior of the potential customers towards the brand.

Not only that, user generated content also contributes in building the reputation of the brand. It is due to the fact that the user generated content created by the customers shows an authenticity value and is one of the prove that the brand's credibility. Because in this era, most customers would prefer a company or a brand which has a good reputation. As stated by (Burton \& Soboleva, 2011, p. 497) current customers can potentially become independent endorser which can build credibility that will lead into brand trust of the company or the brand.

Note that this only applies when it comes to positive user generated content. A positive user generated content can contribute to the company's financial gains and also reputation (Aksoy et al., 2010, p. 299). In contrast, a negative user generated content from the customers would bring a great disaster to the company as it will ruin the reputation that will lead into a huge loss of profit.

Based on that fact, it is very important for a brand or a company to prevent negative user generated content by customers. In purpose to prevent negative user generated content, a brand or company needs to make sure that they provide the best service quality through good interaction and fully satisfy their customers. The happier the customer gets, the better the user generated content that the customers will create.

\section{Interaction}

When the connection between customers and seller has been established, the process proceeds to the next stage of customer engagement cycle which is the interaction. According to Prahalad 
\& Ramsamy (on Sashi, 2012, p. 262) by interacting with customers, seller will be able to gain new insights regarding the customers' needs which is a very important and useful for their business development.

@Bt21stuff.id is known for always reposting the user generated content created and uploaded by the customers to their Instagram story. From here, the interaction is then being established. The owner of @bt21stuff.id believed that by reposting the user generated content, the customers feel appreciated since their effort and contribution is being noticed. With this, the customer will feel closer to @ Bt21stuff.id and emotional bonds between the customers and the seller will slowly appear.

The statement is proven to be true since according to the findings, it is found that the customers are delighted when their user generated content is being reposted. The customers feel appreciated and it motivates them to interact and engage further with @bt21stuff.id.

As stated by Tikkanen et al. (on Sashi, 2012, p. 261), interaction with the customers through virtual will also allow the brand or company to gain a meaningful input and establish a relationship with the customers.

Therefore, it can be said that small things such as reposting the customers' user generated content is very important in establishing a relationship and motivate the customers to interact further with the brand.

\section{Satisfaction}

When the interaction between the customers and the seller results in satisfaction, the customers will most likely stay connected and will always interact with one another in purpose for an engagement to develop. Thus, in purpose to proceed to the next stage of customer engagement building process, the satisfaction from the interaction process must be achieved (Sashi, 2012, p. 262)

In this part of this discussion, we analyzed the feedback that has been given by @bt21stuff.id towards the user generated content that has been created by the customers to discover whether the customers are already satisfied with the feedback given by @bt21stuff.id in the interaction process.

It is found that most of the time, @bt21stuff.id usually only repost the user generated content without giving any greetings first. However, it is also found that with just being reposted, the customers are already very happy, because it means that @bt21stuff.id noticed their effort. We found that this finding is supported by the fact that @bt21stuff.id already has a good service quality. The customers also stated that in other occasion, @bt21stuff.id oftenly replied to their message. For instance, when BTS (Bangtan Sonyeondan) released a new album and @bt21stuff.id posted an instagram story about it, usually the customers will reply to it because they are excited about it and wanted to share their happiness with their favorite K-Pop online shop. In this case, @bt21stuff.id always reply to their customers messages, even though it's not about ordering something from their shop.

This might be one of the causes of why the customers of @bt21stuff.id are satisfied enough with the feedback given by @bt21stuff.id towards their user generated content. The customers 
also stated that they feel closer and feel more like a friend with the owner of @bt21stuff.id instead of just customer and seller.

However, despite all of the facts that has been stated in the previous paragraph, we think that only by reposting the user generated content created by the customers without greeting them first by saying thank you, or any other greetings is not enough. In the theoretical explanation by (Sashi, 2012, p. 262), it is stated that satisfaction in interaction is very important in the customer engagement building process so that the customer would stay connected and continue to interact with the brand. Therefore, the researcher believes that only by reposting the user generated content created by the customer is not enough, despite the fact that the customer is already satisfied enough with the feedback given by @bt21stuff through reposting the user generated content created by the customer, they should at least do something more to express their gratitude towards the customers user generated content.

\section{Retention and Commitment}

We decided to combine the retention and commitment stage into one part of the analysis since based on the findings, we believe that both retention and commitment stage are very similar, and are highly related with each other.

It is found that the main informants, which are the customers of @bt21stuff.id had done repeated purchase for more than 3 times, and also created the user generated content for @bt21stuff.id for more than 3 times also. Therefore, this means that the customers had already reached the retention stage.

The customers of @bt21stuff.id stated that they prefer @bt21stuff.id instead of other online shopping entrusted goods service for K-Pop goods since based on their opinion and personal experience, @bt21stuff.id is more trustable and is known for its good reputation. $@$ Bt21stuff.id already has a lot of positive user generated content from their customers in the form of photo or video review through instagram story that they put on their highlight. As stated in the previous analysis, @bt21stuff.id's service quality is also one of the reasons why they love @bt21stuff.id.

As stated by (Burton \& Soboleva, 2011, p. 497) current customers can potentially become independent endorser which can build credibility that will lead into brand trust of the company or the brand. Another theoretical explanation by (Naem \& Okafor, 2019, p. 203) also supported this finding. They stated that marketers in this era can increase current amount of transparency and trust in brands by allowing user generated content (Naem \& Okafor, 2019, p. 203).

It is also found that the customers already reached the commitment stage. In this case, we believe that the customers of @bt21stuff.id is more into the affective commitment instead of calculative commitment. We came up with this conclusion supported by the fact that the customers decided to continuously buy goods through @bt21stuff.id because they already love the brand. Not because they are lack of choices. This shows that the relationship between the customer and @bt21stuff.id is good.

The feedback given by @bt21stuff.id towards the customers' user generated content is also one of the factors than can result in reciprocity. Since by reposting the customers' user generated 
content, the customers will feel appreciated, involved, and closer with @bt21stuff.id which can result in a long-term relationship.

However, even though the user generated content content plays an important part in building the retention and commitment of the customers, the service quality of a brand is still the most important part in purpose to achieve this stage. Therefore, it is important for a business to also maintain their service quality.

\section{Advocacy}

Customers who are satisfied with a product, service, or brand will more likely to share their positive experience with their peers, or to the audience on their social media (Sashi, 2012, p. 263). He also stated that loyal customers that is lacking emotional bonds with the seller may not share their positive experience with their peers or to the audience. However, delighted customers with high emotional bonds can potentially turn into fans of the brand and will voluntarily recommend the brand to their peers or audience through their social media. Customers who have already become fans are both delighted and loyal to the brand (Sashi, 2012 p. 264).

Since the customers of @bt21stuff.id have created user generated content for more than 3 times and are loyal customers of @bt21stuff.id because they've purchase products for more than 3 times, it is found that the customers had already became the advocate for the business. Therefore, to know more regarding their motivation of sharing the user generated content to their instagram story as a form of advocacy towards @bt21stuff.id, we are using the uses and gratification theory to discover the driving motivations of of consumers' online brand related activities (COBRAs) in the form of user generated content by implementing the newest model of uses and gratification theory by (Buzeta et al., 2020).

Buzeta et al., (2020, p. 80) propose 6 uses and gratification theory as driving motivations of the social media usage by the audience which include entertainment, integration and social interaction, personal identity, information, remuneration, and empowerment.

After a thorough interview and analysis, we found that the customers are mostly motivated by empowerment and also entertainment. Based on the findings, most of the customers stated that they posted the user generated content because they want to influence other people, and it made them happy when their peers or followers got influenced by their user generated content. Not only that, they also stated that one of the core reasons of why they uploaded the user generated content upon purchasing goods from @bt21stuff.id is that they want to help @bt21stuff.id. The customers want a lot of people to know that @bt21stuff.id is a good and trustable place to shop. It is also found that none of the customers receive any financial rewards from @bt21stuff.id whether in the form of discounts, coupons for the next purchase etc.Therefore in conclusion, since the customers are uploading the user generated content voluntarily, it can be said that the customers of @bt21stuff.id had become an advocate for them.

\section{Engagement}

The process can proceed to an engagement when satisfied and happy customers share their positive experience with their peers about the product, service, brand or company that they interact with (Sashi, 2012, p. 264). As stated in the previous part of this paper, the customers 
of @bt21stuff.id have become the advocate for @bt21stuff.id since they voluntarily share their positive experience with their peers through traditional word of mouth and or to their followers through user generated content about @bt21stuff.id.

We believe that the customers are also already become fans of @bt21stuff.id since they are both delighted and loyal to @bt21stuff.id. This is concluded by looking at the fact that the customers have made repeated purchase from @bt21stuff.id for more than 3 times and have shared their positive experience with @bt21stuff.id for more than 3 times also whether traditionally through word of mouth or through user generated content. An engagement occurs not only when the customers are loyal to the brand, but also when the customers contribute to the brand-related activities because they are delighted.

An engagement can also occur when there's two-way interaction and communication between the seller and the buyer that can lead into long-term relationship. During our interview, the customers of @bt21stuff.id stated that their relationship with the owner of @bt21stuff.id surpass common seller-buyer relationship, which in most case the seller and buyer will only interact and communicate with each other when it comes to ordering a product. However, in @bt21stuff.id is different. The customers of @bt21stuff.id can have an interaction and communicate with @bt21stuff.id outside of purchasing context. As stated by the customers of @bt21stuff.id, they are more like a friend with the owner of @bt21stuff.id. This might also be supported by the fact that the owner of @bt21stuff.id is also a fan of K-Pop, more specifically a fan of BTS (Bangtan Sonyeondan). The customers stated that @bt21stuff.id is very responsive towards their messages even though it's not about them ordering stuff from @bt21stuff.id, but it's about them talking about their favourite K-Pop group, BTS. That become one of the reasons of why they love @bt21stuff.id and would want to engage further with them.

Therefore, it can be concluded that the customers of @bt21stuff.id has reached the final stage of the customer engagement cycle which is engagement since they've become favourable towards @bt21stuff.id, already become an advocate for them, and have a high relationship quality, which then lead into loyalty and long-term relationship that can build an engagement.

\section{CONCLUSION}

This research found that the user generated content plays a crucial role in the customer engagement building process. The user generated content contribute most to the interaction, retention, commitment and advocacy stage of customer engagement building process, since in the interaction stage, user generated content is able to establish an emotional bonds between@bt21stuff.id and the customers, since by reposting the user generated content created by the customers, the customers will feel appreciated and involved in the business which can result in satisfaction from the interaction process. As in the commitment and retention stage, user generated content contributes in building trust that will result in a longterm relationship. A long-term relationship will make the customer willingly give a voluntary contribution to @bt21stuff.id which then can build an engagement. For the advocacy stage, the driving motivations of the user generated content creations are including entertainment and empowerment. However it is found that mostly it is caused due to empowerment, since 
the customers of @bt21stuff.id created the user generated content to influence their peers or their social media audience to also purchase goods from @bt21stuff.id.

The researchers would like to suggest further research to do a more in-depth interview with more informants. Since in doing this research, the researchers were limited by the time factor to study more regarding the contribution of user generated content in the customer engagement building process. The researchers would also like to suggest further research to measure the customer engagement through quantitative analysis, so that it can reached broader number of @bt21stuff.id's customers and obtain a more accurate measure through numerical data to study further on the customer engagement of @bt21stuff.id.

Meanwhile for practical implication, the researchers would like to suggest @bt21stuff.id to hire more employee to assist the owner in handling the social media and build interaction with the customers. Since the researchers found that interaction is one of the important factors in the customer engagement building process and it can be improved more to drive the customers into creating user generated content voluntarily after purchasing goods from @bt21stuff.id.

\section{REFERENCES}

Bruns, A. (2016). User-Generated Content. In Bruhn Jensen, Klaus, Craig, Robert T., Pooley, Jefferson D., \& Rothenbuhler, Eric W. (Eds.) The International Encyclopedia of Communication Theory and Philosophy.John Wiley \& Sons. https://doi.org/10.1002/9781118766804.wbiecto85

Burton, S. \& Soboleva, A. (2011). Interactive or reactive? Marketing with Twitter. Journal of Consumer Marketing, 28(7), 491-499. https://doi.org/10.1108/07363761111181473

Buzeta, C., Palsmacker, P. D., \& Dens, N. (2020). Motivations to Use Different Social Media Types and Their Impact on Consumers' Online Brand-Related Activities (COBRAs). Journal of Interactive Marketing, $\quad 52, \quad 79-98$. https://doi.org/10.1016/j.intmar.2020.04.004

Christodoulides, G., Jevons, C., \& Bonhomme, J. (2012). Memo to Marketers: Quantitative Evidence for Change. How User-Generated Content Really Affects Brands. Journal of Advertising Research, 52(1), 3-64. https://doi.org/ 10.2501/JAR-52-1-053-064

Kemp, S. (2021, February 11), Digital 2021: Indonesia. DATAREPORTAL. https://datareportal.com/reports/digital-2021-indonesia

Dunne, A., Lawlor, M. A., \& Rowley, J. (2010). Young people's use of online social networking sites - a uses and gratifications perspective. Journal of Research in Interactive Marketing, 4(1), 46-58. https://doi.org/10.1108/17505931011033551

Gómez, M., Lopez, C., \& Molina, A. (2019). An integrated model of social media brand engagement. Computers in Human Behavior, 96, 196-206. https://doi.org/10.1016/J.CHB.2019.01.026 
Jaakkola, E. \& Alexander, M. (2014). The role of customer engagement behavior in value cocreation. A service system perspective. Journal of Service Research, 17(3), 247-261. https://doi.org/10.1177/1094670514529187

Kim, Y. J. (2021, February 4). \#KpopTwitter achieves new record of 6.7 billion Tweets $\begin{array}{llll}\text { globally in } 2020 . & \text { Twitter }\end{array}$ https://blog.twitter.com/en_us/topics/insights/2021/kpoptwitter-achieves-newrecord-of-6-billion-tweets-globally-in-2020

Larivière, B., Bowen, D., Andreassen, T. W., Kunz, W., Sirianni, N. J., Voss, C., Wunderlich, N. C., \& Keyser, A. D. (2017). "Service Encounter 2.0": An investigation into the roles of technology, employees and customers. Journal of Business Research, 79, 238-246. https://doi.org10.1016/j.jbusres.2017.03.008

Moleong, L. J. (2011). Metodologi Penelitian Kualitatif Edisi Revisi. Remaja Rosdakarya.

Naem, M., \& Okafor, S. (2019). User-Generated Content and Consumer Brand Engagement. In G. Bowen, \& W. Ozuem (Eds.), Leveraging Computer-Mediated Marketing Environments (pp. 193-220). IGI Global. http://doi:10.4018/978-1-5225-7344-9.choo9

Ngai, E. W. T., Tao, S. S. C., \& Moon, K. K. L. (2015). Social media research: Theories, constructs, and conceptual frameworks. International Journal of Information Management, 35(1), 33-44. https://doi.org/10.1016/j.ijinfomgt.2014.09.004

Nurudin. (2019). Pengantar Komunikasi Massa. Raja Grafindo Persada.

Pantalon, K. (2020, September 25). Twitter Charts Growth of KPop as One of its Most Popular Topics. Branding in Asia. https://www.brandinginasia.com/celebrating-10years-of-kpoptwitter-in-20-markets-worldwide/

Patton, M. (2002). Qualitative Research and Evaluation Methods (3rd Ed.). Sage Publications.

Putri, A. R. (2019). POLA KOMUNIKASI ANTARA PENYEDIA JASA TITIP BELI (JASTIP) DENGAN KONSUMEN DALAM BERBELANJA MELALUI INSTAGRAM (Studi Pada Pola Komunikasi Jastip@herhabit.jastip dengan Konsumennya) (Publication No. 15748) [Undergraduate Thesis, Universitas Sriwijaya]. Sriwijaya University Repository.

Qysthina, E., Saerang, D. P. E., \& Rumokoy, F. S. (2018). Social Media as a Medium of Customer Engagement: Case Study Facebook Forum Jual-Beli in Sulawesi Utara. Jurnal EMBA, 6(4), 3753-3762. https://doi.org/10.35794/emba.v6i4.21901

Rachmawati, I. M. (2007). Pengumpulan Data Dalam Penelitian Kualitatif: Wawancara. Jurnal Keperawatan Indonesia, 11(1), 35-40. https://doi.org/ 10.7454/jki.v11i1.184

Rohadian, S. \& Amir, M. T. (2019). Upaya Membangun Customer Engagement Melalui Media Sosial Instagram: Studi kasus online shop yang menjual produknya sendiri. Journal of 
Entrepreneurship, Management and Industry, 2(4), 179-187. http://dx.doi.org/10.36782/jemi.v2i4.1925

Sashi, C. M. (2012). Customer engagement, buyer-seller relationships, and social media. Management Decision, 5o(2), 253-272. https://doi.org/10.1108/00251741211203551

Shawky, S., Kubacki, K., Dietrich, T., \& Weaven, S. (2020). A dynamic framework for managing customer engagement on social media. Journal of Business Research, 121, 567577. https://doi.org/10.1016/j.jbusres.2020.03.030

Sherman, A. \& Smith, D. E. (2013). Social Media Engagement for Dummies. John Wiley \& Sons.

Strauss, J. \& Frost, R. (2011). E-Marketing (6th ed.). Pearson.

Sugiyono. (2015). Metode Penelitian Kombinasi (Mix Methods). Alfabeta.

Suyanto, B. (2005). Metode Penelitian Sosial. Kencana Prenada Media Group. 